Samuka Vol.5 No.2 : hlm 187-196

SAMUKA

Jurnal Samudra Ekonomika

https://ejurnalunsam.id/index.php/jse

\title{
FAKTOR FAKTOR YANG MEMPENGARUHI MINAT MUZAKKI MEMBAYAR ZAKAT DI BADAN BAITUL MAL KOTA LANGSA
}

\author{
Ramadhan Alfitrah ${ }^{1}$, Nurlina ${ }^{2}$, Muhammad Salman ${ }^{3}$ \\ ramadhanalfitrah45@gmail.com \\ nurlina@unsam.ac.id \\ muhammadsalman@unsam.ac.id \\ 1,2,3 Fakultas Ekonomi Universitas Samudra, Langsa \\ Jl. Prof. Dr. Syarief Thayeb, Meurandeh,Kota Langsa, Aceh 24416
}

Received: Sepetember 2021; Accepted: Sepetember 2021; Published: Sepetember 2021

\begin{abstract}
Abstrak
Penelitian ini bertujuan untuk mengetahui pengaruh kepercayaan, transparansi dan tingkat religiusitas terhadap minat muzakki membayar zakat di Badan Baitul Mal Kota Langsa. Sumber data dalam penelitian ini yaitu data primer dimana metode pengambilan data menggunakan kuesioner yang disebar kepada masyarakat kota Langsa yang sudah memenuhi persyaratan untuk membayar zakat. Jumlah sampel yang datanya berhasil diolah yaitu sebanyak 96 orang. Metode pemilihan sampel yang digunakan adalah metode non probability sampling, sedangkan tekhnik pengambilan sampel adalah incendental sampling. Hasil penelitian menunjukkan $\mathrm{Y}=6,366+$ $0,401 \mathrm{X}_{1}+0,275 \mathrm{X}_{2}+0,94 \mathrm{X}_{3}+$ e. Secara parsial menunjukkan bahwa Kepercayaan dan Transparansi memiliki pengaruh yang signifikan terhadap minat muzakki membayar zakat di Badan Baitul Mal Kota Langsa, sedangkan Tingkat Religiusitas tidak memiliki pengaruh yang signifikan terhadap minat muzakki membayar zakat di Badan Baitul Mal Kota Langsa. Hasil penelitian secara simultan menunjukkan bahwa secara bersama sama atau simultan variabel kepercayaan, transparansi dan tingkat religiusitas memilki pengaruh yang signifikan terhadap minat muzakki membayar zakat di Badan Baitul Mal Kota Langsa. Nilai R Square 51,4\% menunjukkan bahwa kepercayaan, transparansi dan tingkat religiusitas terhadap minat muzakki membayar zakat di Badan Baitul Mal Kota Langsa adalah 51,4\%. Sedangkan 48,6\% dipengaruhi oleh faktor lain diluar model penelitian ini.
\end{abstract}

Kata Kunci : Kepercayaan, Transparansi, Tingkat Religiusitas Dan Minat Muzakki

\begin{abstract}
Abstrac
This study aims to determine the effect of trust, transparency and level of religiosity on the interest of muzakki in paying zakat at the Baitul Mal Agency, Langsa City. The source of data in this study is primary data where the data collection method uses a questionnaire distributed to the people of Langsa city who have met the requirements to pay zakat. The number of samples whose data was successfully processed was 96 people. The sample selection method used is non-probability sampling method, while the sampling technique is incidental sampling. The results showed $\mathrm{Y}=6.366+0.401 \mathrm{X} 1+0.275 \mathrm{X} 2+0.94 \mathrm{X} 3+\mathrm{e}$. Partially shows that Trust and Transparency have a significant influence on the interest of muzakki in paying zakat at the Baitul Mal Agency of Langsa City, while the level of religiosity does not have a significant effect on the interest of muzakki in paying zakat at the Baitul Mal Agency of Langsa City. Simultaneous research results show that simultaneously or simultaneously the variables of trust, transparency and level of religiosity have a significant influence on the interest of muzakki in paying zakat at the Baitul Mal Agency, Langsa City. The R Square value of $51.4 \%$ indicates that trust, transparency and the level of religiosity towards muzakki's interest in paying zakat at the Baitul Mal Agency in Langsa City are $51.4 \%$. While $48.6 \%$ is influenced by other factors outside this research model.
\end{abstract}

Keywords: trust, transparency, level of religiosity and interest of muzakki 


\section{PENDAHULUAN}

Zakat adalah salah satu rukun islam yang merupakan kewajiban bagi umat muslim untuk menunaikannya. Zakat memiliki arti untuk mensucikan dan kegiatan yang berhubungan dengan membayar zakat dianggap sebagai bentuk investasi sosial (Raam Al Jaffri Saad, 2014). Peraturan tentang pengelolaan zakat di Indonesia diatur dalam undang-undang nomor 23 Tahun 2011 serta Peraturan Standar Akuntansi Keuangan (PSAK) No. 109 untuk menyamakan bentuk laporan keuangan dari transaksi zakat itu sendiri. Pembayaran zakat merupakan suatu kewajiban bagi umat muslim, sama hal nya dengan pajak, zakat juga memiliki ketentuan dan peraturan sesuai dengan standar yang telah ditetapkan. Zakat juga dibebankan kepada pihak atau lembaga tertentu yang sudah memenuhi syarat. Perbedaan zakat dan pajak adalah, zakat diwajibkan untuk umat muslim diseluruh dunia yang telah memenuhi syarat dan ketentuan, sedangkan pajak merupakan kewajiban yang dikenakan kepada pihak atau badan yang ada disuatu negara dengan tidak membedakan antara umat beragama.

Zakat termasuk dalam institusi resmi untuk menciptakan pemerataan dan keadailan, sehingga dapat meningkatkan taraf kehidupan masyarakat (Shahnaz, 2016). Pelaksanaan zakat dapat dilakukan secara efektif melalui lembaga zakat formal, yaitu BAZNAS (Badan Amil Zakat) dan LAZ (Lembaga Amil Zakat) (Rahman, 2015). Amil zakat memiliki karakteristik sebagai organisasi nirlaba sebagaimana dimaksud dalam Pernyataan Standar Akuntansi Keuangan (PSAK nomor 45, yakni memperoleh sumber daya dari muzakki yang tidak mengharapkan imbalan apapun atau manfaat ekonomi yang sebanding dengan jumlah sumber daya yang diberikan, menghasilkan barang dan jasa tanpa bertujuan memupuk laba, dan tidak ada kepemilikan dalam artian bahwa kepemilikan tidak dapat dijual, dialihkan, diambil kembali, atau kepemilikan tersebut tidak mencerminkan proporsi pembagian sumber daya pada saat likuidasi atau pembubaran (Teten Kustiawan dkk, 2012)

Potensi zakat di Indonesia Rp 233,8 triliun dan yang terkumpul hanya Rp 8,1 triliun (3,5 persen) (Outlook Zakat Indonesia 2020). Bedasarkan data tersebut terlihat ketimpangan yang sangat menonjol antara potensi zakat dengan zakat yang terkumpul melalui lembaga pengelola zakat. Di Indonesia ada beberapa kendala yang membuat penerimaan zakat masih minim. Pertama, dari sisi edukasi dan literasi. Menurut Direktur Pendistribusian dan Pemberdayaan BAZNAS, Irfan Syauqi Beik, rendahnya pemahaman masyarakat selama ini tentang ekonomi Islam termasuk didalamnya tentang manfaat zakat untuk meningkatkan perekonomian Islam zakat, sehingga ada beberapa masyarkat yang sudah memenuhi persyaratan wajib zakat, tidak mau membayar zakat. Kedua, perlu penguatan kapasitas kelembagaan dan sumber daya manusia (SDM) baik di BAZNAZ pada tingkat nasional, hingga kabupaten/kota. Ketiga, mayoritas muzakki lebih memilih membayar zakatnya secara langsung kepada mustahiq dari pada melalui lembaga zakat(lokadata.id).

Kota Langsa, merupakan sebuah kota yang mayoritas masyarakatnya beragama Islam. Hal ini menjadikan Kota Langsa sebagai salah satu daerah yang mempunyai potensi zakat yang cukup besar. Potensi zakat di Kota Langsa pada tahun 2019 Rp.10.603.521.480, jumlah ini didapatkan dari nilai Pendapatan Domestik Bruto Kota Langsa tahun 2019 Rp. 530.181.074.000 yang dikali kan dengan 2\%. ${ }^{1}$ Zakat yang terkumpul di Badan Baitul Mal Kota Langsa Rp.3.037.238.498 atau 35\% dari potensi zakat. ${ }^{2}$ Untuk mengukur potensi zakat di suatu daerah dapat digunakan proporsi tertentu dari Pendapatan Domestik Regional Bruto di suatu daerah yang dikalikan dengan opini zakat di Indonesia yaitu $2 \%$ (Ahmed,2008). Berdasarkan data tersebut, terlihat bahwa zakat yang terkumpul masih relatif sedikit. Ini menunjukkan bahwa masih rendahnya minat muzakki membayar zakat kepada Badan Baitul

\footnotetext{
${ }^{1}$ Data BPS Kota Langsa http://langsakota.bps.go.id/ dilihat pada tanggal 03 Februari 2021

${ }^{2}$ Badan Baitul Mal Langsa. Laporan Muzakki Tahun 2019
} 
Mal Kota Langsa, sehingga menjadi penyebab ketimpangan antara besaran potensi zakat dengan realisasi penerimaan zakat.

\section{LANDASAN TEORI}

\section{Teori Hierarki Kebutuhan dari Abraham Harold Maslow}

Setiap manusia memiliki ketertarikan dalam memilih sesutu pekerjaan. Minat adalah sesuatu di dalam diri manusia yang memberi energi, yang mengaktifkan dan menggerakkan ke arah perilaku untuk mencapai tujuan tertentu. Zakat termasuk dalam kategori kebutuhan setiap umat muslim yang telah memenuhi persyaratanuntuk membayar zakat. Penjelasan mengenai konsep minat manusia menurut Maslow (1954:35) mengacu pada lima kebutuhan pokok yang disusun secara hierarkis. Kebutuhan hierarkis tersebut terdiri dari :

1. Kebutuhan fisiologis (physiological needs)

Kebutuhan ini mencakup perkembangan konsepsi homeostatis yakni usaha tubuh untuk mempertahankan aliran darah agar tetap normal dan selera individu yang berbeda - beda dalam kaitannya dengan kebutuhan tubuh.

Jika kebutuhan ini tidak terpenuhi maka kebutuhan yang lain akan tenggelam dan tidak akan memengaruhinya, misalnya ketika individu lapar dan haus ia menjadi sulit berkonsentrasi atau bahkan melakukan kegiatan lainnya.

2. Kebutuhan Keamanan (safety needs)

Kebutuhan seseorang akan keamanan dan perlindungan dari hal yang tidak baik merupakan sebuah kebutuhan yang sangat foundamental bagi setiap individu.(Gibson,1996)

3. Kebutuhan Sosial (social needs)

Individu akan merasakan perlunya hubungan dengan orang lain sebagai makhluk sosial, ia tidak akan bertahan lama dengan rasa kesendirian, apalagi jika ia menjadi orang yang ditolak dari lingkungannya. Kebutuhan ini termasuk kebutuhan untuk memberi dan menerima perhatian dari orang lain.

4. Kebutuhan Penghargaan (esteem needs)

Individu akan memiliki dua kebutuhan akan penghargaan, yakni harga diri dan penghargaan dari orang lain. Seseorang yang memiliki cukup penghargaan akan merasa lebih percaya diri, mampu, atau bahkan lebih produktif. Sebaliknya jika penghargaan dirinya rendah maka ia akan memiliki rasa tidak percaya diri yang akan menimbulkan keputus-asaan atau bahkan perilaku neurotic.

5. Kebutuhan Aktualisasi Diri (self-actualization needs)

Kebutuhan seseorang akan pertumbuhan, pencapaian potensi seseorang, dan pemenuhan diri serta dorongan untuk mampu menjadi apa yang diinginkan.

\section{Minat}

Menurut Kamus Besar Bahasa Indonesia (KBBI), minat adalah kecenderungan hati yang tinggi, gairah atau keinginan terhadap sesuatu. Minat merupakan suatu kondisi yang terjadi yang berhubungan dengan kebutuhan atau keinginan sendiri. Dengan kata lain terjadi suatu kecenderungan tentang apa yang dilihat dan diamati oleh seseorang adalah sesuatu yang berhubungan dengan keinginan dan kebutuhan seseorang tersebut, minat seseorang terhadap suatu objek menjadikan perhatian orang tersebut selalu tertuju kepada objek. Minat juga dapat dianggap sebagai rencana atau keinginan untuk sukses dalam mencapai suatu tujuan.

Minat adalah suatu keadaan di mana seseorang mempunyai ketertarikan, perhatian terhadap sesuatu disertai keinginan untuk mengetahui, mempelajari dan mengambil tindakan untuk membuktikannya. Minat muncul karena adanya perhatian yang mendalam terhadap suatu objek, di mana kemudian perhatian itu menimbulkan keinginan untuk mengetahui, mempelajari serta membuktikan lebih lanjut. Minat memerlukan sebuah motivasi dan keyakinaan agar dapat 


\section{Zakat}

Ditinjau dari segi bahasa, kata zakat merupakan kata dasar dari zaka yang berarti berkembang, suci, tumbuh, dan berkah. Perkataan zakat diartikan dengan suci, tumbuh dan, serta berkah. Jika pengertian ini dihubungkan dengan harta, maka dalam ajaran Islam, harta yang dizakati akan tumbuh berkembang, bertambah karena suci, dan membawa keberkahan dan kebaikan hidup bagi yang memiliki harta. Adapun dari segi istilah fiqih, zakat berarti sejumlah harta tertentu yang diwajibkan kepada setiap orang untuk diserahkan kepada orang orang yang berhak menerimanya. (Hafidhuddin, 2002).

\section{Pengertian Kepercayaan}

Kepercayaan (trust) merupakan keyakinan bahwa tindakan orang lain atau suatu kelompok sesuai dengan yang mereka yakini. Kepercayaan lahir dari suatu proses secara perlahan kemudian terakumulasi menjadi suatu bentuk kepercayaan, dengan kata lain kepercayaan adalah keyakinan seseorang bahwa di satu produk ada atribut tertentu. Keyakinan ini muncul dari persepsi yang berulang adanya pembelajaran dan pengalaman (Rouf, 2014: $34)$.

Kepercayaan secara umum akan dipandang sebagai unsur yang mendasar dalam keberhasilan suatu hubungan, tanpa adanya suatu kepercayaan, maka hubungan tidak akan mampu bertahan untuk jangka waktu yang lama. Menurut Ikhwanda (2018) kepercayaan adalah pengetahuan dan kesimpulan seorang konsumen tentang suatu obyek, atribut, dan manfaatnya. Obyek nya yaitu bisa berupa sebuah produk seperti barang, manusia, perusahaan, dan lembaga. Atribut merupakan karakteristik atau fitur yang dimiliki atau tidak dimiliki oleh suatu obyek. Kepercayaan muzakki terhadap lembaga pengelola zakat berasal dari pengetahuan dan kesimpulan muzakki tentang lembaga pengelola zakat, muzakki yang telah memiliki kepercayaan kepada suatu lembaga pengelola zakat, maka ia akan tetap membayarkan zakatnya kepada lembaga pengelola zakat tersebut.

\section{Tranparansi}

Menurut Mardiasmo dalam (Maryati, 2012), transparansi merupakan keterbukaan pemerintah dalam memberikan informasi terkait dengan aktivitas pengelolaan sumber daya publik kepada pihak yang membutuhkan informasi. Pemerintah memiliki kewajiban dalam memberikan informasi keuangan dan informasi lainnya yang akan digunakan untuk pengambilan keputusan oleh pihak yang berkepentingan. Informasi yang dimaksud adalah mengenai setiap aspek lembaga yang bisa dijangkau publik. Keterbukaan informasi diharapkan akan menghasilkan manajemen lembaga yang sehat dan berdasarkan kepentingan masyarakat.

Transparansi adalah penyampaian laporan keuangan kepada semua pihak yang membutuhkan secara terbuka, yang digunakan sebagai landasan pengambilan keputusan dan proses pelaksanaan kegiatan. Membangun transparansi dalam pengelolaan zakat akan menciptakan sistem kontrol yang baik antara dua pihak yaitu lembaga dan stakeholder, karena tidak hanya melibatkan pihak intern organisasi (lembaga zakat) saja tetapi lebih kepada pihak ekstern yaitu muzakki atau masyarakat secara luas.( Ashari,2016)

\section{Pengertian Tingkat Religiusitas}

Menurut Yazid (2017) religiusitas merupakan pengabdian terhadap agama, dan juga dapat diartikan suatu pengabdian seorang muzakki terhadap ajaran agama islam dengan menunaikan kewajiban untuk mengeluarkan zakatnya dari hartanya yang telah mencapai nisab. Menurut Satrio dan Siswantoro (2016) religiusitas adalah nilai dari pemahaman seseorang terhadap norma syari'ah, khususnya terkait dengan kewajiban zakat yang sangat mempengaruhi kesadaran seseorang untuk mengeluarkan sakat kepada mustahiq. Pada hakikatnya religiusitas merupakan suatu hal yang sangat penting dalam kehidupan manusia, karena setiap perbuatan yang dilakukan manusia di dunia ini akan di pertanggungjawabkan di akhirat. Sehingga dapat kita pahami bahwa dalam beraktivitas agama itu berkaitan erat dengan 
religiusitas, karena kita di dunia ini bukan hanya melakukan suatu serangkaian ibadah saja melainkan juga pada aktivitas

Tingkat religiusitas merupakan faktor dimana umat islam dengan pemahaman tingkat agama yang tinggi maka diharapkan akan lebih sadar dalam kewajiban membayar zakat dibandingkan dengan muslim dengan tingkat agama yang rendah. Dengan tingkat religiusitas yang tinggi maka akan mendorong seseorang untuk memiliki ketaatan yang lebih tinggi, sehingga mendorong seseorang untuk taat dalam mengeluarkan zakat secara rutin (Satrio dan Siswantoro, 2016).

\section{Kerangka Pemikiran}

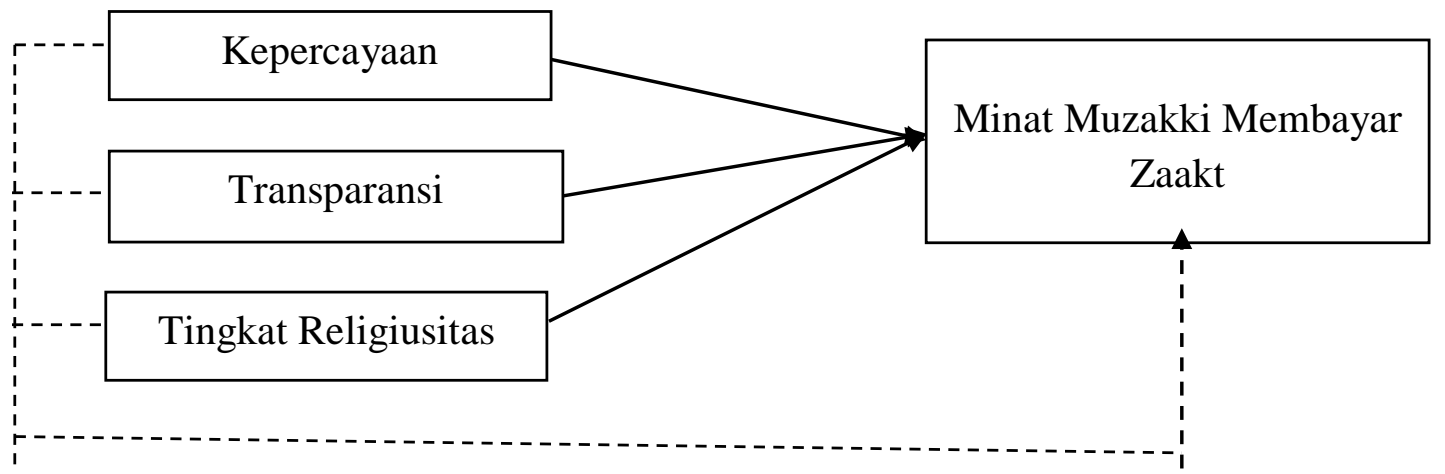

Sumber : Penelitian. 2021

Gambar 1. Kerangka Pemikiran

\section{METODE PENELITIAN}

\section{Ruang Lingkup dan Lokasi Penelitian}

Penelitian ini untuk menguji pengaruh Kepercayaan, Transparansi dan Tingkat Religiusitas sebagai variabel independen terhadap variabel dependen Minat Muzakki Membayar Zakat. Lokasi penelitian ini dilaksanakan di Badan Baitul Mal Kota Langsa. Jalan. Ahmad Yani No. 18 A, Komplek Gedung Cakra Donya, Gampong Peukan Langsa, Kecamatan Langsa Kota, Kota Langsa, Aceh 24375.Ruang lingkup penelitian ini pada konsentrasi akuntansi sektor publik Penelitian ini dilakukan dalam jangka waktu 8 bulan (Desember 2020Juli 2021).

\section{Jenis dan Sumber Data}

Jenis data yang digunakan dalam penelitian ini adalah data kuantitatif. metode kuantitatif adalah metode penelitian yang digunakan untuk meneliti sampel tertentu berdasarkan data yang berbentuk angka atau bersifat kuantitatif dengan tujuan untuk menguji hipotesis yang telah ditetapkan.

Sumber data yang digunakan dalam penelitain ini terdiri dari sumber data primer dan sumber data sekunder. Sumber data primer adalah data yang diperoleh atau yang dikumpulkan langsung di lapangan oleh orang yang melakukan penelitian atau yang bersanggutan yang memerlukannya. Dalam penelitian ini data primer di ambil dari pengumpulan kuesioner yang diberikan kepada responden. Sumber data sekunder adalah data yang diterbitkan atau digunakan oleh organisasi yang tersedia. Sumber data sekunder dalam penelitian ini adalah data yang dikeluarkan oleh Badan Baitul Mal Kota Langsa.

\section{Populasi dan Sampel}

Menurut Sugiyono (2014) menyatakan bahwa populasi adalah wilayah generalisasi yang terdiri atas objek/subyek yang mempunyai kuantitas dan karakteristik tertentu yang ditetapkan oleh peneliti untuk dipelajari dan kemudian ditarik kesimpulannya. Populasi dalam penelitian ini pengunjung objek wisata hutan mangrove Kota Langsa. Menurut Sugiyono 
(2014), sampel merupakan bagian dari jumlah dan karakteristik yang dimiliki oleh populasi tersebut.

Metode pengambilan sampel dalam penelitian ini menggunakan metode non probability sampling. Non probability sampling merupakan teknik pengambilan sampel yang tidak memberikan peluang atau kesempatan yang sama bagi setiap unsur atau anggota populasi untuk dipilih menjadi anggota sampel Sedangkan teknik pengambilan sampel menggunakan incidental sampling yaitu teknik penentuan sampel berdasarkan kebetulan, yaitu siapa saja yang secara kebetulan bertemu dengan peneliti dapat dijadikan sampel jika orang yang ditemui dipandang cocok dengan sumber data (Sugiono, 2015).

Populasi dalam penelitian ini tidak diketahui jumlahnya sehingga untuk menghitung jumlah sampel minimum yang dibutuhkan menggunakan formula Lemeshow untuk populasi yang tidak diketahui (Snedecor dan Chocran, 2015:75).

Keterangan:

$$
n=\frac{Z^{2} X p(1-p)}{d^{2}}
$$

$\mathrm{n}=$ Jumlah sampel

$\mathrm{Z}=$ skor $\mathrm{z}$ pada kepercayaan $95 \%=1,96$

$\mathrm{p}=$ maksimal estimasi $=0,5$

$\mathrm{d}=$ alpha $(0.1)$ atau sampling error $=10 \%$

$$
\begin{gathered}
n=\frac{Z^{2} X p(1-p)}{d^{2}} \\
n=\frac{1,96^{2} X 0,5(1-0,5)}{0,1^{2}} \\
n=\frac{3,84 X 0,5(1-0,5)}{0.01} \\
n=96
\end{gathered}
$$

Dari hasil perhitungan tersebut maka diketahui besar sampel yang diperlukan adalah 96 responden.

\section{Metode Pengumpulan Data}

Untuk menghasilkan data dan informasi yang baik dan bermutu, penulis menggunakan beberapa metode pengumpulan data secara efektif dan efisien,yaitu:

1. Wawancara, yaitu pengumpulan data yang digunakan untuk memperoleh informasi langsung dari sumbernya

2. Observasi, yaitu salah satu metode pengumpulan data secara sengaja, terarah, sistematis dan terencana sesuai tujuan yang di capai dengan mengamati dan mencatat fenomena yang mengacu pada penelitian.

3. Angket/kuesioner, yaitu pemberian daftar pertanyaan kepada responden yang di lengkapi dengan alternatif jawaban. Proses pengambilan data dilakukan dengan membuat pertanyaan atau pernyataan yang kemudian disebarkan kepada responden untuk di jawab. Skala penelitian yang di gunakan dalam penelitian ini yaitu berdasarkan skala pengukuran likert.

\section{Metode Analisis Data}

Untuk mengetahui pengaruh variabel bebas $\left(\mathrm{X}_{1}, \mathrm{X}_{2}, \mathrm{X}_{3}\right)$ terhadap variabel terikat $(\mathrm{Y})$ digunakan analisis regresi linier berganda (Sunyoto, 2010:29):

$$
\mathbf{Y}=\mathbf{a}+\mathbf{b}_{1} \mathbf{X}_{1}+\mathbf{b}_{2} \mathbf{X}_{2}+\mathbf{b}_{3} \mathbf{X}_{3} \ldots+\mathbf{b}_{\mathbf{n}} \mathbf{X}_{\mathbf{n}}+\mathbf{e}
$$

Pengujian hipotesis dilakukan dengan alat bantu stastitik Uji t yang digunakan untuk menguji secara parsial dan Uji F yang digunakan untuk menguji secara simultan.

Dimana : 


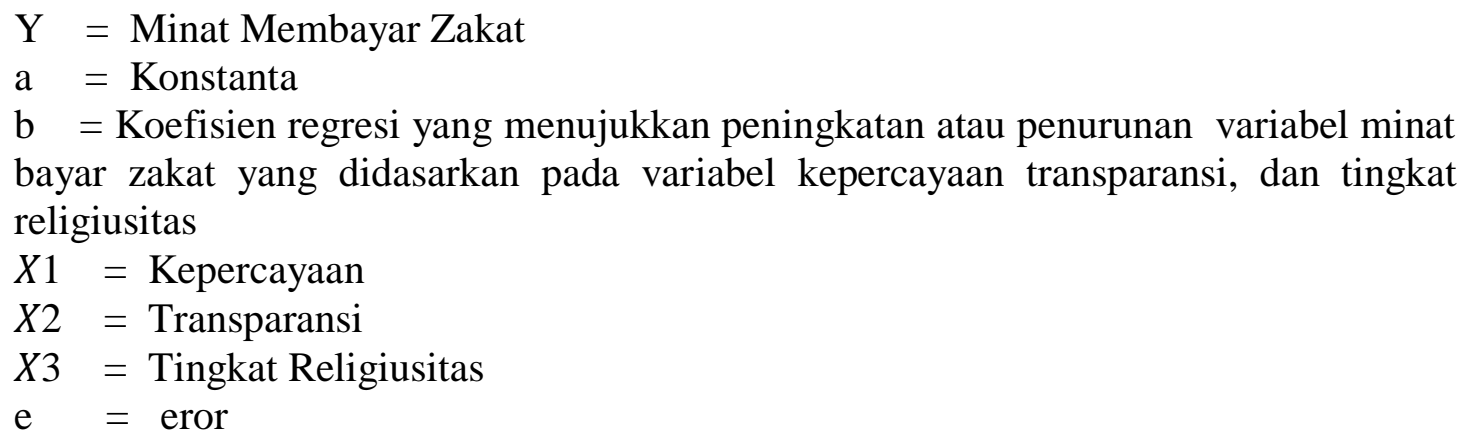

\section{HASIL DAN PEMBAHASAN}

\section{Uji Koefisien Regresi Linier Berganda}

Untuk mengetahui pengaruh kepercayaan( $\left.X_{1}\right)$, transparansi (X2) dan tingkat religiusitas, $\left(\mathrm{X}_{3}\right)$. terhadap minat muzakki membayar zakat di Badan Baitul Mal Kota Langsa(Y), maka digunakan analisis regresi linear berganda.

Tabel 1. Analisis Regresi Linear Berganda

\begin{tabular}{|c|c|c|c|c|c|c|c|c|}
\hline \multicolumn{9}{|c|}{ Coefficients $^{\mathrm{a}}$} \\
\hline & & \multicolumn{2}{|c|}{$\begin{array}{l}\text { Unstandardized } \\
\text { Coefficients }\end{array}$} & \multirow{2}{*}{$\begin{array}{c}\begin{array}{c}\text { Standardiz } \\
\text { ed } \\
\text { Coefficient } \\
\text { s }\end{array} \\
\\
\text { Beta } \\
\end{array}$} & \multirow[b]{2}{*}{$\mathrm{t}$} & \multirow[b]{2}{*}{ Sig. } & \multicolumn{2}{|c|}{$\begin{array}{l}\text { Collinearity } \\
\text { Statistics }\end{array}$} \\
\hline Model & & B & $\begin{array}{l}\text { Std. } \\
\text { Error }\end{array}$ & & & & $\begin{array}{c}\text { Toleran } \\
\text { ce }\end{array}$ & VIF \\
\hline \multirow[t]{4}{*}{1} & (Constant) & 6,366 & 3,806 & & 1,672 & ,098 & & \\
\hline & Kepercayaan &, 401 &, 117 & ,385 & 3,411 & 001 & ,496 & 2,017 \\
\hline & Transparansi &, 275 &, 103 & 291 & 2,681 & ,009 &, 535 & 1,871 \\
\hline & $\begin{array}{l}\text { Tingkat } \\
\text { Religiusitas }\end{array}$ & ,094 &, 120 & ,067 & ,785 & ,434 & ,868 & 1,152 \\
\hline
\end{tabular}

Sumber: Data Primer yang diolah, 2021

Berdasarkan hasil tabel diatas, maka diperoleh persamaan grafik sebagai berikut.=:

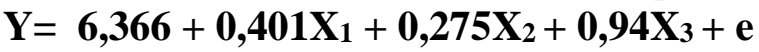

Berdasarkan hasil persamaan regresi berganda di atas memberikan pengertian bahwa:

1. Nilai konstanta 6,366, artinya jika variabel kepercayaan, transparansi dan tingkat religiusitas dianggap konstan maka minat muzakki untuk membayar zakat di Baitul Mal meningkat sebesar 6,366 .

2. Berdasarkan persamaan regresi menunjukkan bahwa variabel tingkat kepercayaan $\left(X_{1}\right)$, mempunyai arah koefisien regresi positif dengan minat membayar zakat yaitu $b=0,401$, yang berarti bahwa apabila variabel kepercayaan mengalami peningkatan sebesar $1 \%$ maka minat muzakki untuk membayar zakat di Baitul Mal akan meningkat sebesar $40 \%$ dengan asumsi bahwa variabel independen yang lain konstan.

3. Berdasarkan persamaan regresi menunjukkan bahwa variabel transparansi $\left(\mathrm{X}_{2}\right)$, mempunyai arah koefisien regresi positif dengan minat membayar zakat yaitu $b=0,275$, yang berarti bahwa apabila variabel pemahaman mengalami peningkatan sebesar $1 \%$ minat muzakki untuk membayar zakat di Baitul Mal akan meningkat 27,5 \% dengan asumsi bahwa variabel independen yang lain konstan.

4. Berdasarkan persamaan regresi menunjukkan bahwa variabel tingkat religiusitas $\left(X_{3}\right)$, mempunyai arah koefisien regresi positif dengan minat membayar zakat yaitu $b=0,094$, yang berarti bahwa apabila variabel budaya mengalami peningkatan sebesar $1 \%$ maka minat muzakki untuk membayar zakat di Baitul Mal akan meningkat 9,4\% dengan asumsi bahwa variabel independen yang lain konstan. 


\section{Hasil Uji t (Parsial)}

Tabel 2. Hasil Uji t

\begin{tabular}{|c|c|c|c|c|c|c|c|c|}
\hline \multicolumn{9}{|c|}{ Coefficients $^{\mathrm{a}}$} \\
\hline & & \multicolumn{2}{|c|}{$\begin{array}{c}\text { Unstandardized } \\
\text { Coefficients }\end{array}$} & \multirow{2}{*}{$\begin{array}{c}\text { Standardiz } \\
\text { ed } \\
\text { Coefficient } \\
\text { s } \\
\text { Beta }\end{array}$} & \multirow[b]{2}{*}{$\mathrm{t}$} & \multirow[b]{2}{*}{ Sig. } & \multicolumn{2}{|c|}{$\begin{array}{l}\text { Collinearity } \\
\text { Statistics }\end{array}$} \\
\hline Model & & B & $\begin{array}{l}\text { Std. } \\
\text { Error }\end{array}$ & & & & $\begin{array}{c}\text { Toleran } \\
\text { ce }\end{array}$ & VIF \\
\hline \multirow[t]{4}{*}{1} & (Constant) & 6,366 & 3,806 & & 1,672 & ,098 & & \\
\hline & Kepercayaan &, 401 &, 117 & ,385 & 3,411 &, 001 & ,496 & 2,017 \\
\hline & Transparansi & 275 &, 103 & ,291 & 2,681 & .009 & .535 & 1,871 \\
\hline & $\begin{array}{l}\text { Tingkat } \\
\text { Religiusitas }\end{array}$ & ,094 & , 120 &, 067 & ,785 & ,434 & ,868 & 1,152 \\
\hline
\end{tabular}

Berdasarkan hasil tabel diatas, maka diperoleh hasil sebagai berikut:

1. Pembuktian secara parsial menunjukkan variabel kepercayaan memiliki tanda positif dengan thitung sebesar 3,411. Sedangkan t tabel untuk taraf signifikansi 5\% adalah sebesar 1,986. Nilai signifikansi variabel kepercayaan adalah sebesar 0,001 , sehingga nilai signifikansi $<0,05$. Karena signifikansi $<0,05$ maka variabel kepercayaan memiliki pengaruh yang signifikan terhadap minat muzakki membayar zakat di Badan Baitul Mal Kota Langsa.

2. Pembuktian secara parsial menunjukkan variabel 1 transparansi memiliki tanda positif dengan thitung sebesar 2,681. Sedangkan t tabel untuk taraf signifikansi 5\% adalah sebesar 1,986,. Nilai signifikansi variabel transparansi adalah sebesar 0,009 , sehingga nilai signifikansi < 0,05. Karena signifikansi > 0,05 maka variabel transparansi memiliki pengaruh yang signifikan terhadap minat muzakki membayar zakat di Badan Baitul Mal Kota Langsa.

3. Pembuktian secara parsial menunjukkan variabel tingkat religiusitas memiliki tanda positif dengan $\mathrm{t}$ hitung sebesar 0,785. Sedangkan ttabel untuk taraf signifikansi 5\% adalah sebesar 1,986, Nilai signifikansi variabel tingkat religiusitas adalah sebesar 0,434, sehingga nilai signifikansi $>0,05$. Karena nilai signifikansi $>$ dari 0,05 maka tingkat religiusitas tidak memiliki pengaruh yang signifikan terhadap minat muzakki membayar zakat di Badan Baitul Mal Kota Langsa.

\section{Hasil Uji f (simultan)}

Tabel 3. Hasil Uji f

\begin{tabular}{|c|c|c|c|c|c|c|c|c|}
\hline \multicolumn{9}{|c|}{ Coefficients $^{\mathbf{a}}$} \\
\hline & & \multicolumn{2}{|c|}{$\begin{array}{l}\text { Unstandardized } \\
\text { Coefficients }\end{array}$} & \multirow{2}{*}{$\begin{array}{c}\begin{array}{c}\text { Standardiz } \\
\text { ed }\end{array} \\
\text { Coefficient } \\
\text { s }\end{array}$} & \multirow[b]{2}{*}{$\mathrm{t}$} & \multirow[b]{2}{*}{ Sig. } & \multicolumn{2}{|c|}{$\begin{array}{l}\text { Collinearity } \\
\text { Statistics }\end{array}$} \\
\hline Model & & B & $\begin{array}{l}\text { Std. } \\
\text { Error }\end{array}$ & & & & $\begin{array}{l}\text { Toleran } \\
\text { ce }\end{array}$ & VIF \\
\hline \multirow[t]{4}{*}{1} & (Constant) & 6,366 & 3,806 & & 1,672 &, 098 & & \\
\hline & Kepercayaan & ,401 &, 117 & ,385 & 3,411 & ,001 & ,496 & 2,017 \\
\hline & Transparansi & 275 & 103 & 291 & 2,681 &, 009 &, 535 & 1,871 \\
\hline & $\begin{array}{l}\text { Tingkat } \\
\text { Religiusitas }\end{array}$ &, 094 &, 120 &, 067 &, 785 & ,434 & ,868 & 1,152 \\
\hline
\end{tabular}


Dari tabel di atas dapat diketahui bahwa nilai signifikansi untuk pengaruh $\mathrm{X}_{1}, \mathrm{X}_{2}$ dan $\mathrm{X}_{3}$ secara simultan terhadap Y adalah sebesar $0,000<$ dari $\alpha=0.05$ dan nilai $\mathrm{F}$ hitung sebesar 22,134 > F tabel 2,70, Maka dapat disimpulkan bahwa H1 diterima dan H0 ditolak, yang berarti menunjukkan bahwa secara bersama sama atau simultan kepercayaan, transparansi dan tingkat religiusitas berpengaruh signifikan terhadap minat muzakki membayar zakat di di Badan Baitul Mal Kota Langsa.

\section{Hasil Uji Koefisien Determinasi $\left(\mathbf{R}^{2}\right)$}

Tabel 2. Hasil Uji t Hasil Uji Koefisien Determinasi $\left(\mathbf{R}^{2}\right)$

\begin{tabular}{|c|c|c|c|c|}
\hline \multicolumn{5}{|c|}{ Model Summary ${ }^{b}$} \\
\hline Model & $\mathrm{R}$ & R Square & $\begin{array}{l}\text { Adjusted R } \\
\text { Square }\end{array}$ & $\begin{array}{l}\text { Std. Error of } \\
\text { the Estimate }\end{array}$ \\
\hline 1 &, $710^{\mathrm{a}}$ &, 514 &, 502 & 2,523 \\
\hline \multicolumn{5}{|c|}{$\begin{array}{l}\text { a Predictors: (Constant), Tingkat Religiusitas(X3), } \\
\text { Transparansi(X2), Kepercayaan (X1) }\end{array}$} \\
\hline b. Depe & at Varial & le: Minat $\mathrm{N}$ & mbayar Zakat & \\
\hline
\end{tabular}

Dari tabel diatas diketahui bahwa nilai $\mathrm{R}$ sebesar 0,710 berarti kemampuan menjelaskan variabel kepercayaan, transparaansi dan tingkat religiusitas terhadap minat muzakki membayar zakat di Badan Baitul Mal Kota Langsa baik karena nilai mendekati satu. Nilai R Square 0,514 berarti 51,4\% faktor yang mempengaruhi minat muzakki membayar zakat di Badan Baitul Mal Kota Langsa dapat dijelaskan oleh faktor transparaansi dan tingkat religiusitas. Sedangkan $48,6 \%$ dijelaskan oleh faktor lain diluar model penelitian ini.

\section{KESIMPULAN}

Berdasarkan analisis dan pengujian data dalam penelitian ini, maka dapat di tarik kesimpulan, Kepercayaan memiliki pengaruh signifikan terhadap minat muzakki minat muzakki membayar zakat di Badan Baitul Mal Kota Langsa.

1. Transparansi memiliki pengaruh signifikan terhadap minat muzakki minat muzakki membayar zakat di Badan Baitul Mal Kota Langsa.

2. Tingkat religiusitas tidak memiliki pengaruh signifikan terhadap minat muzakki minat muzakki membayar zakat di Badan Baitul Mal Kota Langsa.

3. Kepercayaan, tranparansi dan tingkat religiusitas secara bersama sama/ simultan memiliki pengaruh signifikan terhadap minat muzakki minat muzakki membayar zakat di Badan Baitul Mal Kota Langsa.

\section{REFERENSI}

Ahmed, H., 2008. "Zakat, Ekonomi Makro Kebijakan dan Pengentasan Kemiskinan: Pelajarandari Simulasi di Bangladesh ".Jurnal Ekonomi Islam, Perbankan dan Keuangan (2). Tersedia di http: // www.ibtra.com/pdf/journal/v4_n2_article4.pdf. Diakses 15 Maret 2021

Abdullah, M.,dan Sapiei, N.S. (2018). Do religiosity, gender and educational background influence zakat compliance? The case of Malaysia. International Journal Of Social Economics,Vol. 45 No. 8, 1250-1264.

Alpriyamah Qurotu Uyun dan Adityawarman . 2017 Analisis Faktor-Faktor Yang Mempengaruhi Perilaku Kepatuhan (Compliance Behavior) Pembayaran Zakat Perdagangan (Studi Kasus Pengusaha Muslim Batik di Kota Pekalongan) Diponegoro Journal Of Accounting Volume 6, Nomor 3, Halaman 1-13

Andini, Ayu .2020.Penerimaan zakat, besar potensi minim realisasi.25 Januari 2020.https://lokadata.id/artikel/penerimaan-zakat-besar-potensi-minim-realisasi

Badan Baitul Mal Kota Langsa. 2019. Laporan Muzakki 2019 
Data BPS Kota Langsa http://langsakota.bps.go.id/ dilihat pada tanggal 03 Februari 2021

Depdiknas. Undang undang RI Nomor 23 Tahun 2011. Tentang Pengelolaan Zakat di Indonesia.

Ikatan Akuntansi Indonesia (2008). PSAK NO.109 : Akuntansi Zakat dan Infak/Sedekah. Dewan Standar Akuntansi Keuangan Ikatan Akuntan Indonesia.

Ikhwanda, M. F. (2018). Pengaruh Transparansi, Akuntabilitas, Kepercayaan Afektif dan Kognitif Terhadap Minat Bayar Zakat Melalui Lembaga Zakat. Skripsi. Universitas Islam Indonesia Yogyakarta

Kurniati, S. (2015). Analisis Faktor-Faktor Yang Mempengaruhi Minat Muzakki Membayar Zakat, Infaq Dan Shadaqah Di LAZIS RSI PKU Muhammadiyah Pekajangan (Studi Kasus Karyawan RSI PKU Muhammadiyah Pekajangan). Skripsi. Stain Pekalongan

Mendari, Anastasia Sri. Aplikasi Teori Hirarki Kebutuhan Maslow dalam Meningkatkan Motivasi Belajar, Jurnal Widya Warta No.1, 2010.

Mardiasmo. 2002 Akuntansi Sektor Publik, Yogyakarta: ANDI Yogyakarta,

Nugraha, J. (2014). Pengantar Analisis Data Kategorik : Metode dan Aplikasi Menggunakan Program R . Yogyakarta: Deepublisher.

Outlook zakat Indonesia 2020 Jakarta : BAZNAS.

Qanun Nomor 10 Tahun 2018 Tentang Baitul Mal Pemerintahan Aceh.

Rouf, M. A. (2014). Analisis Faktor-Faktor yang Mempengaruhi Minat Masyarakat Membayar Zakat di Rumah Zakat Cabang Semarang. Skripsi.IAIN Walisongo

Satrio, E.,dan Siswantoro, D. (2016). Analisis factor pendapatan, kepercayaan dan religiusitas dalam mempengaruhi minat muzakki untuk membayar zakat penghasilan melalui lembaga amil zakat. Lampung : Simposium Nasional Akuntansi XIX, Hal 1-20

Septiarini, D.F. (2011). Pengaruh transparansi dan akuntabilitas terhadap pengumpulan dana zakat, infaq dan shodaqoh pada LAZ di Surabaya. Fakultas Ekonomi \& Bisnis Universitas Airlangga, Akrual 2 (2) : 172-199 E-Issn: 2502-6380. XIX 